\title{
PELATIHAN TRIK MENCIPTAKAN PELUANG USAHA UNTUK KARYAWAN BUMNAG KENAGARIAN MALAY V SUKU TIMUR
}

\author{
Yusnaena ${ }^{1}$, \\ Haryeni $^{2}$, \\ Erdasti Husni ${ }^{3}$ \\ Deddi Julianto ${ }^{4}$ \\ Program Studi Manajemen Perusahaan \\ Fakultas Ekonomi Universitas Dharma Andalas Padang \\ Email :ayuwidara72@gmail.com
}

\begin{abstract}
Abstrak
Kegiatan ini dilakukan pada Badan usaha milik Nagari dikenagarian Malay V Suku timur team mengindikasi Berdasarkan hasil wawancara dilapangan terindikasi bahwa badan usaha ini sama sekali belum produktif, belum ada usaha apapun yang telah jalan. modal yang tersedia belum berfungsi untuk menumbuh kembangkan perekonomian masyarakatnya, padahal berdasarkan data-data kenagarian banyak bidang usaha yang bisa dibina, karena kenagarian ini kenagarian yang produktif, namun hal ini tidak berkorelasi dengan semangat dalam mengelola badan usaha kenagarian ini, hasil wawancara kami dengan walinagari terlihat anggota belum menemukan aktifitas wirausaha seperti apa yang akan mereka lakukan untuk memproduktifkan Bumnag ini.Berdasarkan fenomena diatas maka tim kami akan memberikan pelatihan dan penyuluhan kepada masyarakat Kenagarian Malay V Suku Timur ini untuk memberikan pengetahuan bagaimana menciptakan sebuah wirausaha, yang kami kemas dalam topik" Trik melahirkan Wirausaha" Setelah diadakan kegiatan ini maka BUMNAG ini telah aktif dan mulai beraktifitas.

Tujuan dilakukannya kegiatan ini untuk mengaktifkan keberadaan dan usaha Nagari di kenagarian dan memberikan ilmu kewirausahaan untuk anggotanya agar mampu mengelola keberadaan sebuah badan usaha milik nagari yang sudah mereka miliki . Kegiatan ini akan diikuti karyawan Bumnag Kenagarian V Suku malay Timur sebanyak lebih kurang 15 orang.
\end{abstract}

Keyword : Manajemen Kewirausahaan

\section{PENDAHULUAN}

Badan Usaha Milik Nagari adalah Lembaga Usaha Nagari yang dikelola oleh Masyarakat dan Pemerintah Nagari dalam upaya memperkuat perekonomi nagari dan di bentuk berdasarkan kebutuhan dan potensi nagari. Ciri Utama BUMNag dengan Lembaga Ekonomi Komersil lainya,sebagai berikut : Badan Usaha ini dimiliki oleh nagari dan dikelolah bersama. Modal bersumber dari desa sebesar $100 \%$ dan dari masyarakat yang sesuai kebutuhan bersama. Operasionalisasinya menggunakan falsafah bisnis yang berakar dari budaya lokal Bidang usaha yang dijalankan berdasarkan pada potensi dan informasi pasar Keuntungan yang di peroleh di tunjukan untuk meningkatkan kesejahteraan anggota (Penyetara Modal ) dan masyarakat melalui kebijakan nagari. Difasilitasi oleh Pemerintah Propinisi,Pemerintah Kabupaten dan Pemerintahaan Operasionalisasi di Ekonomi, Sosial, dan Budaya 
kontrol secara bersama oleh BAMUS,Pemerintah Nagari dan Anggota) BUMNag sebagai suatu lembaga ekonomi modal usahanya dibangun atas inisiatif masyarakat dan menganut asas mandiri. Ini berarti pemenuhan modal usaha BUMNag harus bersumber dari masyarakat. Meskipun demikian, tidak menutup kemungkinan BUMNag dapat mengajukan pinjaman modal kepada pihak luar, seperti dari Pemerintah Kabupaten Kotaatau pihak lain, bahkan melalui pihak ketiga. Ini sesuai dengan peraturan per undang-undangan (UU 32 tahun 2004 tentang Pemerintahan Daerah Pasal 213 ayat 3). Penjelasan ini sangat penting untuk mempersiapkan pendirian BUMNag, karena implikasinya akan bersentuhan dengan pengaturannya dalam Peraturan Daerah (Perda) maupun Peraturan Nagari (Perna) Tujuan Pendirian BUMNag: Empat tujuan pendirian BUMNag,diantaranya sebagai berikut : Meningkatkan Perekonomian Nagari Meningkatkan Pendapatan asli Nagari Meningkatkan Pengelolaan potensi nagari sesuai dengan kebutuhan masyarakat Menjadi tulang punggung pertumbuhan dan pemerataan ekonomi nagari Pendirian dan pengelolaan Badan Usaha Milik Desa adalah perwujudan dari pengelolaan ekonomi produksif desa yang dilakukan secara Koorperatif,Partisifatif,Emansipatif,Transparansi, Akuntabel dan Sustaniabel. Oleh karena itu perlu upaya serius untuk menjadikan pengelolaan Badan Usaha Milik Desa dapat berjalan secara mandiri,efektif,efisien dan profesional. Guna mencapai tujuan BUMDes dilakukan dengan cara memenuhi kebutuhan (Produktif dan Konsumtif) masyarakat melalui pelayanan barang dan jasa yang dikelolah oleh masyarakat dan pemerintah desa. Lembaga ini juga dituntut mampu memberikan pelayanan kepada non anggota (pihak luar Desa) dengan menempatkan harga dan pelayanan sesuai standar pasar. Artinya terdapat mekanisme kelembagaan yang disepakati bersama, sehingga tidak menimbulkan disorsi ekonomi pedesaan disebabkan oleh usaha BUMDes. Berdasarkan paparan diatas jelas sudah bahwa Bunag adalah sebuah badan usaha yang dimiliki oleh nagari, demikian juga dengan Kenagarian Malay V Suku Timur sebuah kenagarian baru hasil dari pemekaran wilayah Malay V suku yang terletak di kabupaten Padang Pariaman. Sebagai sebuah kenagarianpun memiliki sebuah badan usaha yang dinamakan Bumnag tadi, namun sesuai dengan tujuan dibentuknya badan usaha ini antara lain untuk Meningkatkan Perekonomian Nagari Meningkatkan Pendapatan asli Nagari Meningkatkan Pengelolaan potensi nagari sesuai dengan kebutuhan masyarakat Menjadi tulang punggung pertumbuhan dan pemerataan ekonomi nagari Pendirian dan pengelolaan Badan Usaha Milik Desa adalah perwujudan dari pengelolaan ekonomi produksif desa yang dilakukan secara Koorperatif,Partisifatif,Emansipatif,Transparansi,

Akuntabel dan Sustaniabel belum terlihat di kenagarian Malay V Suku Timur ini. Berdasarkan hasil wawancara kami dilapangan mengindikasikan bahwa badan usaha ini sama sekali belum produktif, belum ada usaha apapun yang dijalankannya sehingga modal yang ada belum berfungsi untuk menumbuh kembangkan perekonomian masyarakatnya, padahal berdasarkan data-data kenagarian banyak bidang usaha yang bisa dibina melalui keberadaan Bunag ini, karena kenagiaran ini adalah kenagarian yang prudktif, dimana kegiatan masyarakatnya yang sebahagian besar memiliki kebun yang luas, seperti kebun kelapa, kebun jagung, kebun buah naga dan bahkan sarana dan prasarana tersedia dengan lengkap. Seperti jalan raya yang beraspal bagus, masyarakat yang rajin dan ramah tamah,pemuda yang bersemangat namun kenapa hal ini tidak berkorelasi dengan semangat dalam mengelola badan usaha kenagarian ini, ada apa dan mengapa.....? untuk menjawab masalah sementara hasil wawancara kami dengan walinagari terlihat masyarakat bingung dan belum menemukan aktifitas wirausaha seperti apa yang akan mereka lakukan untuk memproduktifkan keberadaan dari Bumnag ini, Sehingga Bumnag ini antara ada dan tiada, ada karena mereka sudah memiliki Modal dan sarananya namun tiada karena modal dan sarana yang ada tadi belum mampu mereka kelola melalui sebuah usaha yang mampu meningkatkan eonomi masyarakatnya sesuai dengan tujuan keberadaan Bumnang tadi. Berdasarkan fenomena diatas maka tim kami akan memberikan pelatihan dan penyuluhan kepada masyarakat Kenagarian Malay V Suku Timur ini untuk memberikan pengetahuan bagaimana menciptakan sebuah peluang usaha, yang kami kemas dalam topik" Trik menciptakan peluang usaha " diharapkan dengan adanya penyuluhan ini memberikan ilmu pengetahuan sekaligus berupa pencerahan kepada masyarakat sehingga mengetahui dan paham bagaimana

Ekonomi, Sosial, dan Budaya 1465 
memulai sebuah usaha sehingga menimbulkan motivasi dan kemampuan mereka untuk melirik sebuah usaha yang akan dikelola melalui keberadaan Bumnag tadi, karena selama ini badan usaha ini belum lagi mendapatkan pelatihan dan penyuluhan dari pihak manapun juga.

\section{METODE}

Metode pelaksanaan kegiatan dalam mengatasi masalah mitra untuk mencapai tujuan dalam program ini adalah :

A. Rencana Kegiatan bersama mitra yang menunjukkan langkah-langkah solusi atas permasalahan prioritas mitra selama 4 (empat ) Bulan .

Adapun rencana kegiatan yang akan dilakukan selama empat bulan untuk memberikan solusi atas permasalahan mitra adalah akan dilaksanakan dengan metode pendekatan melalui Pelatihan dan penyuluhan serta pendampingan terhadap mitra binaan dengan materi seputaran manajemen kewirausahaan

Pelaksanaannya dengan komposisi sebagai berikut : Metode dan strategi penyampaian materi dilakukan dengan kegiatan :

Ceramah dan Penyuluhan /pendampingan : $40 \%$

Role play $20 \%$

Participatory: $20 \%$

Active learning : $20 \%$

\section{Evaluasi dan pelaksanaan program dan keberlanjutan program.}

Evaluasi dan pelaksanaan program kegiatan serta keberlanjutannya akan dilakukan secara periodik selama program berjalan dan sesudah selesainya kegiatan program tersebut sehingga mitra binaan benar-benar merasakan arti dari kerjasama tim dengan mitra binaan, karena berakhirnya kegiatan ini anggota mitra binaan akan memiliki pengetahuan yang lebih baik dari semula dalam bekerja . Setelah kegiatan ini berakhir, tim akan selalu memantau dan mengikuti perkembangan pertumbuhan kegiatan aktifitas kewirausahaan yang dijalankan di Bumnag Malay V Suku Timur ini. dan selalu membimbing dalam pengelolaan manajemen yang baik mereka secara kontiniu dan jika didalam perjalanan mereka menemukan masalah , tim akan senantiasa membantu mitra binaan. Dan akan selalu membangun jembatan hati dengan masyarakat demi menjalin kedekatan dengan masyarakat untuk membangun nagari sehingga dengan kokohnya sebuah nagari akan melahirkan pemerintahan nagari yang kokoh juga yang akhirnya mampu memperkokoh keberadan bangsa Indonesia ini.

\section{HASIL DAN PEMBAHASAN}

Sehubungan dengan belum adanya aktifitas pada badan usaha nagari ( Bumnag) tersebut maka kami dari team pengabdian kepada masyarakat memberikan penyuluhan bagaimana untuk membuka atau menciptakan sebuah aktifitas usaha pada Bumnag tersebut, dengan memberikan materi tentang trik-trik kewirausahaan, dalam menciptakan sebuah peluang usaha.

\section{A Trik Menciptakan Peluang Usaha}

Hampir sebagian besar orang memimpikan menjadi seorang pebisnis besar dan sukses. Tapi, hanya sebagian kecil yang benar-benar hidup menjalani mimpi tersebut. Alasannya sederhana, merintis dan mengelola usaha sendiri tidak semudah yang dibayangkan. Selain harus memiliki mental sekuat baja, ada hal penting lain yang harus dipersiapkan matang.

\section{Yakinkan dirimu}

Mulailah untuk lebih memantapkan hati sebelum memutuskan pilihanmu. Apabila masih setengah hati saat mulai membangun usaha, Anda akan lebih mudah dijatuhkan oleh keadaan. Alih-alih sukses, usaha yang Anda bangun justru berhenti di tengah jalan.

\section{Persiapkan model bisnis yang akan dijalankan}

Jika hati sudah mantap, cobalah untuk mulai memikirkan model bisnis apa yang akan Anda 
jalankan nanti. Anda bisa mulai mencari tahu informasi tren bisnis yang sedang berkembang.

\section{Berpikir "Out of The Box"}

Tidak ada pebisnis yang sukses tanpa berpikir kreatif. Bisnis transportasi online misalnya, ia melihat peluang bagaimana bisnis ini nantinya menjadi solusi masyarakat urban. Nah, jadi biasakan untuk mengasah kemampuan berpikir menjadi lebih kreatif ya.

\section{Siapkan "Visi dan Misi" yang jelas}

Hal terpenting saat akan memulai usaha adalah membuat rencana bisnis yang memiliki fleksibilitas dan inovasi bisnis di dalamnya, jangan lupa sertakan "Visi dan Misi" yang jelas usaha yang tengah Anda rintis.

\section{Organisir diri}

Mulailah dengan membiasakan diri lebih terorganisir. Hal ini sangat penting sebagai modal diri dalam mengatur usaha Anda. Sederhananya, jika Anda tak bisa mengorganisir diri, bagaimana Anda akan mengorganisir semua elemen bisnis Anda?

\section{Rajin membuat catatan}

Catat semua hal penting yang Anda dapat. Mulai dari nasihat orang lain, hingga tantangan-tantangan yang Anda hadapi saat mengelola usaha Anda. Dengan harapan, bila waktunya tiba, Anda tak hanya mewariskan sebuah perusahaan melainkan juga pengalaman Anda.

\section{Fokus pada satu bisnis dulu}

Jangan terburu-buru menggandakan keuntungan dengan memulai bisnis ke dua. Pastikan bisnis yang Anda kelola saat ini sudah benar-benar stabil, baik dari segi modal, SDM, maupun kebutuhankebutuhan lainnya.

\section{Siap menghadapi kemungkinan terburuk}

Nyali memang diperlukan untuk benar-benar terun menjadi pebisnis. Namun, itu saja tidak cukup, analisa dan siapkan diri Anda pada kemungkinan terburuk yang bisa saja terjadi.

\section{Terbuka terhadap setiap evaluasi}

Salah satu rahasia kesuksesan adalah "proses belajar". Jadilah orang yang selalu terbuka terhadap kritik dan nasihat dari orang lain. Cobalah untuk melakukan evaluasi terhadap kekurangan diri pada saat berbisnis.

\section{Terus belajar dan jangan cepat puas}

Setiap perjalanan bisnis pasti ada "naik dan turun". Saat bisnis yang Anda kelola sedang di atas angin, jangan cepat puas. Gunakan momentum ini untuk semakin mengakselerasi bisnis. Begitupun pada saat bisnis Anda sedang lesu, jangan lantas putus asa. Buka hati dan jangan malu untuk bertanya kepada pengusaha senior.

\section{Jalankan bisnis yang Anda sukai}

Menjalani sesuatu sesuai dengan passion akan membuat sesorang lebih rileks, bahkan saat sedang diterjang situasi sulit sekalipun. Hal ini juga berlaku di dalam dunia bisnis. Dengan begitu, Anda dijamin tak akan kesulitan dalam mempertahankan komitmen.

\section{Jalankan bisnis yang Anda kuasai}

Bicara bisnis tentu bicara keuntungan. Ada kalanya hal yang Anda sukai kurang menguntungkan, baiknya Anda kesampingkan dulu hal yang Anda sukai dan fokus kepada yang Anda kuasai. Pahami potensi Anda, lalu terapkan ke dalam fokus bisnis Anda.

\section{Siapkan modal usaha}

Sekarang kita bahas faktor eksternal dalam memulai usaha. Pertama-tama soal modal. Pastikan apakah modal dalam bisnis Anda berasal dari dana pribadi atau dari hasil patungan. Bila dari hasil patungan, pastikan semuanya diatur secara jelas, hitam di atas 
putih. Agar nantinya tak ada yang merasa dirugikan saat bagi hasil.

\section{Lihat peluang bisnis}

Sedikit bocoran, sejak beberapa tahun terakhir ini, Pemerintah Indonesia sedang menaruh perhatian besar di sektor perdagangan digital. Nah hal ini adalah contoh peluang bisnis yang dapat Anda manfaatkan. Anda bisa mulai berdagang secara online, atau bahkan mendirikan perusahaan startup berbasis digital.

\section{Tentukan target pasar}

Seorang calon pengusaha yang sukses haruslah pandai menganalisa target pasar. Meski ia memiliki produk dengan kualitas terbaik, namun, jika ia tidak memiliki pasar yang tepat, maka penjualan produk yang dilakukan akan mengalami kesulitan.

\section{Persiapkan operasional}

Pastikan semua kebutuhan bisnis Anda dapat dipenuhi oleh alat atau mesin penunjang operasional. Anda bisa mempersiapkannya dengan cara membeli atau menyewa. Tergantung dangan besarnya modal yang sudah ada.

\section{Pilih SDM yang tepat}

Sumber daya manusia adalah salah faktor krusial apakah bisnis Anda dapat bertahan atau tidak. Sebab tak mungkin Anda mengelola semuanya sendirian. Pastikan SDM yang Anda pekerjakan mendatangkan manfaat alih-alih mudarat.

\section{Pahami kompetisi}

Dunia bisnis adalah dunia yang sarat akan kompetisi. Untuk memenangkan persaingan, cara terbaik adalah mempelajari dan belajar dari pesaing Anda. Jangan malu mengakui keunggulan pesaing Anda, tetapi juga jangan mau kalah. Belajarlah dari keunggulan pesaing Anda, sikapi dengan positif dan cari cara bagaimana Anda bisa menjadi lebih unggul.

\section{Mental baja}

Satu kali pasti bisnis Anda akan mengalami penurunan, bahkan tidak jarang yang mengalami kebangkrutan. Jika dihadapkan pada kondisi ini, jangan memutuskan untuk berhenti. Sebab apa yang sudah dimulai sayang jika tak diselesaikan. Semua yang Anda butuhkan sudah ada di genggaman, pengalaman. Jadikan pengalaman sebagai modal berharga agar nantinya sukses bisa Anda raih.

\section{Action}

Hal terpenting dari membangun bisnis adalah "memulai". Memang tidak gampang, tapi langkah pertama sangat diperlukan. Sukses bukan jatuh dari langit, ia tidak datang sendiri. Sukses didapat lewat perjalanan dan usaha tak kenal lelah. Jadi mulai pijakkan langkah pertama Anda menuju kesuksesan.

Sikap Jiwa Kewirausahaan yang Harus Dimiliki Seorang Pebisnis

1. Mempunyai keberanian dan daya kreasi yang tinggi

2.Mempunyai semangat tinggi dan kemauan keras

3. Mempunyai daya analisis yang benar

4.Mempunyai jiwa pemimpin dan tidak berperilaku konsumtif

5. Membuat keputusan dan melaksanakan keputusan

6. Memiliki pengabdian yang besar terhadap bisnisnya

Tidak hanya untuk dirinya sendiri, pebisnis harus menerapkan jiwa wirausahanya terhadap pelanggan dan calon pelanggan. Untuk menjadi seorang wirausaha yang dapat dikatakan handal dan profesional jika ia melakukan hal - hal berikut ini:

- Sangat mengenal dan meyakini produknya

- Mampu menerima kritik dan saran yang baik dengan tidak berdebat dengan pelanggan maupun calon pelanggan

- Memiliki kemampuan komunikasi yang baik dengan anggotanya maupun pelanggan

- Bersikap yang santun, jujur dan berani mengambil keputusan

Ekonomi, Sosial, dan Budaya

1468 
- Bertanggung jawab jika saja terjadi sesuatu terhadap produk atau jasa dalam bisnisnya yang merugikan pelanggan.

Dengan dilakukannya kegiatan pengabdian ini melalui pemberian ilmu yang berisikan bagaimana untuk memulai usaha, untuk termotivasinya para pengurus bumnag tersebut diharapkan selesainya kegiatan ini Bumnag kenagarian Malay V Suku Timur Pariaman. Bisa beraktifitas sesuai dengan fungsi dan tujuan keberadaannya. Sehingga tujuan adanya badan usaha nagari ini mampu menjawab kebutuhan masyarakat setempat, dan disamping itu dengan beraktifitasnya badan usaha Nagari tersebut sekaligus menjadi wadah bagi masyarakat untuk menyalurkan hasil kebunnya untuk dipasarkan. Dan Badan usaha ini bisa juga menjawab kebutuhan masyarakatnya, Karena daerah ini adalah daerah pertanian dan masyarakatnya mayoritas petani dan perkebunan, maka badan usaha ini bisa juga membuka usaha dalam penyediaan alat alat pertanian serta pupuk untuk petani masyarakat tersebut, sehingga masyarakat tidak perlu jauh-jauh untuk mendapatkan alat-alat pertanian yang dibutuhkannya. Disamping itu karena kenagarian ini jauh dari pusat kota maka Badan usaha ini sejogyaanya bergerak juga dalam hal kebutuhan rumah tangga sehingga masyarakat tidak repot lagi untuk mencari kebutuhannya sehari-sehari.

Foto-foto kegiatan pelatihan .
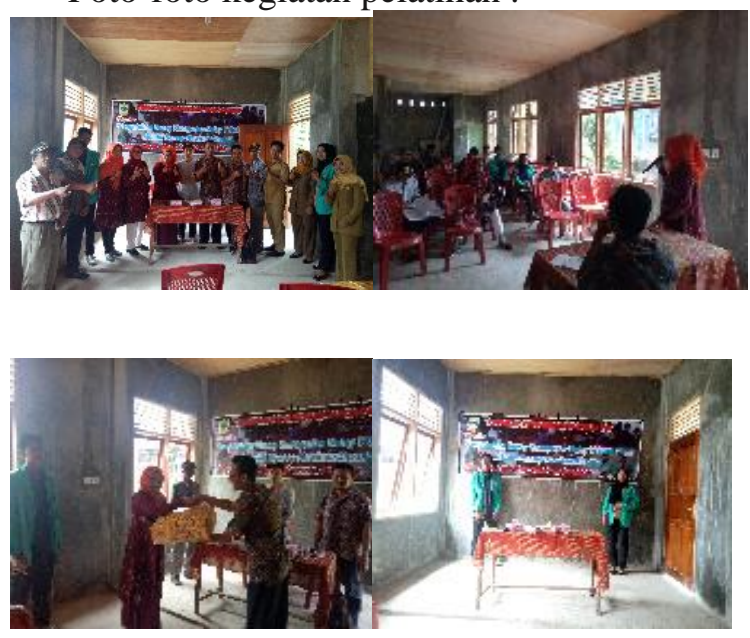

Gambar 1. Pelaksanaan kegiatan

\section{KESIMPULAN}

Dengan dilakukannya kegiatan pengabdian ini melalui pemberian ilmu dengan materi kewirausahaaan yang difokuskan kepada trik untuk memulai usaha. Maka Bumnag Kenagarian Malay V Suku Timur ini telah mulai beroperasi yang sebelumnya kami pun membantu menyusun anggaraan dasar dan anggaran rumah tangga nya terlebih dahulu.

\section{SARAN}

Adapun saran dari team adalah :

1. Dengan telah mulainya beroperasi maka pengurus harus aktif dalam mengembangkan usaha ini

2. Kreatifitas pengurus sangat menentukan tumbuh dan berkembangnya Badan usaha ini,maka dianjurkan agar pengurus untuk kreatif dan inovatif dalam mencari dan mengembangkan Bumnag ini.

3. Wali Nagari harus senantiasa mengawasi kegiatan dari Badan usaha ini sehingga pengurus dan anggota merasa lebih diperhatikan hingga meningkatkan motivasi mereka untuk mengelola Bumnag ini.

\section{UCAPAN TERIMA KASIH}

Dengan terlaksananya kegiatan ini kami dari team pengabdian kepada masyarakat mengucapkan terima kasih kepada :

1. Bapak Prof.DR. Dedi Prima Putra.Apt, selaku Rektor Universitas Dharma Andalas Padang.

2. Ibu Dr.Asniati,SE,MBA,Ak,CA,CSRA selaku DekanUniversitas Dharma Andalas Padang.

3. Semua Unsur LPPM Universitas Dharma Andalas Padang

4. Buat Teman-teman sejawat yang telah turut andil dalam membantu memberikan ide hingga selesainya proposal penelitian ini.

5. Wali Nagari beserta perangkat nagari dan stfaf Malay V Suku Timur yang telah meluangkan waktu dan kesempatan untuk kami bisa melaksanakan kegiatan ini

6. Masyarakat Malay V Suku Timur yang telah berperan aktif dalam membantu terlaksananya kegiatan ini.

7. Dan pihak-pihak lain yang tidak mungkin untuk penulis sebutkan satu-persatu, untuk

$$
\text { Ekonomi, Sosial, dan Budaya }
$$


semua yang telah membantu dan memberikan dorongan kepada penulis dalam menyelesaikan kegiatan ini. Terima kasih atas segala motivasi dan saransarannya.

\section{DAFTAR PERPUSTAKAAN}

Buchari Alma. 2003. Kewirausahaan. Bandung: Alfabeta.

Longenecker, Justin G., et al. 2000. Kewirausahaan: Manajemen Usaha Kecil. Jakarta : Salemba Empat

Ollenburger, Jane C. dan Hellen A. Moore, 1996, Sosiologi Wanita, Jakarta: Rineka Cipta Meredith, Geoffrey G. 2002. Kewirausahaan: Teori dan Praktek. Jakarta : PPM Suryana. 2003. Kewirausahaan: Pedoman Praktis, Kiat dan Proses Menuju Sukses. Jakarta: Salemba Empat.

https://www.scribd.com/document/356748816/Bada

n-Usaha-Milik-Nagari

https://www.liputan6.com/bisnis/read/3166427/20-

tips-sukses-bangun-bisnis-dari-nol 